

\title{
Diversification and agrarian change under environmental constraints in rural China: Evidence from a poor township of Beijing municipality*
}

\author{
Sylvie Démurger \\ GATE, Université Lyon 2 - CNRS, France \\ demurger@gate.cnrs.fr \\ Martin Fournier \\ GATE, Université Lyon 2 - CNRS, France \\ fournier@gate.cnrs.fr \\ Yang Weiyong \\ University of International Business \& Economics, Beijing, China \\ weiyongyang@gmail.com
}

This version: 09/03/2007

\section{Corresponding author:}

Sylvie Démurger

Groupe d'Analyse et de Théorie Economique (GATE)

CNRS UMR 5824 - Université Lyon 2

93, chemin des Mouilles - B.P.167

69131 Ecully cedex - FRANCE

Tel: +33(0) 472866105

Fax: +33(0) 472866090

E-mail: demurger@gate.cnrs.fr

\footnotetext{
* We would like to thank the University of Auvergne (Clermont-Ferrand, France) for funding the survey work in 2003, as well as the Centre National de la Recherche Scientifique (CNRS) and the French Ministry of Research for additional funding. A part of the research was conducted when Sylvie Démurger was visiting the Hong Kong Institute of Economics and Business Strategy (HIEBS) at the University of Hong Kong and when Martin Fournier was a researcher at the French Centre for Research on Contemporary China (CEFC, Hong Kong). The hospitality of both institutions is greatly acknowledged.
} 


\title{
Diversification and agrarian change under environmental constraints in rural China: Evidence from a poor township of Beijing municipality
}

\begin{abstract}
:
This article illustrates the impact of changes related to market reforms and environmental policies on the economic structure in rural China by providing a comparative analysis of several villages in a poor township in Beijing municipality. Two main concomitant phenomena are affecting agricultural and non-agricultural choices in the studied area. First, the introduction of market mechanisms is encouraging local population to engage in new activities that are closer to local comparative advantages. Second, rural households are facing new constraints in the form of environmental protection measures, which have weakened traditional insurance channels provided by forest resources and cattle stock. Drawing on household-level survey data and interviews with village heads conducted in ten villages of Labagoumen township in December 2003, this article analyzes households decisions in response to market reforms and environmental constraints. We find large disparities both between villages and households in the diversification process and discuss the reasons of observed inertia in the region, most households still heavily relying on corn production.
\end{abstract}

Keywords: Agrarian change, Income-source diversification, Environmental protection, Rural China

JEL code: $\mathrm{O} 18, \mathrm{O} 53, \mathrm{P} 25, \mathrm{Q} 10, \mathrm{R} 20$

\section{Introduction}

Over the past decades, developing countries have been showing an outstanding trend of activity diversification in rural areas . A rich related literature suggests that rural households adjust their activities either to seek new opportunities created by market liberalization as it is the case for rice growing regions in southeast $\mathrm{Asia}^{1}$, or to cope with abundant livelihood risks as shown in the large number of studies conducted in environmentally-constrained areas in African countries ${ }^{2}$. These adjustments are found to have an important impact on income, income distribution and welfare of rural households ${ }^{3}$. 
In China, the launching of economic reforms from the end of the 1970s has led to important changes in the production structure in rural areas. Pre-reform central planning and regional auto-subsistence objectives had resulted in a specialization model entirely disconnected from local comparative advantages. Before the reforms, the rural economy was therefore overwhelmingly dominated by agricultural activities, with grain crops accounting for more than 80 per cent of the total sown area.

The reform process has brought deep changes in the incentive structure for rural households. On the one hand, the Household Responsibility System introduced at the end of the 1970s and generalized over the entire country by 1983 , has led to the dismantling of the People's Communes and has progressively given freedom to rural households in their activity choice. On the other hand, the emergence of market mechanisms through price reforms and the development of free markets have enhanced the responsiveness of rural households to relative price changes and encouraged profit-oriented activities. In addition, China's joining the WTO has accelerated structural adjustments in the rural economy, from land-intensive grain production to more labour-intensive activities, including fruits and vegetables crops, animal husbandry and rural industrialisation, for which China has a strong comparative advantage.

As a consequence, China's rural economy has been diversifying at three levels. First, the importance of grain in the farming sector has dropped rapidly in favour of cash crops, whose share has increased from 20 per cent of total sown area in 1978 to 35 per cent in 2003. Second, the agricultural production has shifted to a more diversified structure characterized by a constant decline of farming and a steady rise of husbandry, forestry and fishery in terms of output value. Third, non-farm activities have thriven as illustrated by the prosperity of China's rural enterprises that have become the most dynamic element in the rural economy. Behind these national trends, substantial disparities in the activity diversification process exist between regions, counties, villages, and between households within the same village. 
The outcome of institutional changes brought by economic reforms is made of complex evolutions at the local level, different villages and different households reacting differently to changes. Indeed, local natural, economic and institutional conditions and constraints play a key role in this differentiated impact. As a consequence, local restructuring is faced with a mix of incentives and impediments to.

New constraints imposed by environmental policies that have been implemented in recent years serve as additional catalysts for diversification. Specifically, the implementation of the Natural Forest Protection Program and the Sloping Land Conversion Program from the end of the 1990s has both brought impetus and imposed constraints to structural adjustments in rural areas ${ }^{4}$. On the one hand, these programs have facilitated activity restructuring (such as tourism development) by providing earmarked subsidies or other policy support. On the other hand, the denying of access to forestry and pasture resources may threaten the traditional livelihood of poor households ${ }^{5}$ and impede the process of diversification.

To illustrate the impact of institutional changes related to economic reforms and environmental policies on rural populations and on the rural economic structure, this article focuses on a case study of a poor township in Beijing municipality. Over the last few years, this township has both experienced market reforms and faced forest policy changes. By providing a comparative analysis of several villages in the township, we aim at first, illustrating how rural households adjust their productive structure in response to market reforms and environmental constraints and second, highlighting the reasons for large observed disparities between villages and households in the course of diversification.

The article is organized as follows. Section 2 highlights the diversification pattern observed in Labagoumen (喇叭沟门) township over the recent years. Section 3 discusses the determinants of diversification behaviours at the household level and stresses the reasons why 
diversification has not taken place at a faster pace in Labagoumen. Section 4 analyses the determinants of structural change at the village level. Section 5 concludes.

\section{Study area: forms of diversification in Labagoumen township}

Our research is based upon a series of interviews conducted in December 2003 with local officials (village heads or Party general secretaries) as well as upon a household survey made at the same time and covering 322 households. The surveyed area comprises ten villages in Labagoumen township located in the north of Huairou (怀柔) county, Beijing municipality. The list of the villages as well as their location within the township is given in Map 1 (see also Table 1).

The township government is situated $160 \mathrm{~km}$ away from Beijing city and $93 \mathrm{~km}$ from Huairou county seat. With 302 square kilometres, Labagoumen is the biggest township in Huairou county. It is composed of 15 administrative villages, with a population of almost 7,000 inhabitants (among which one third of Manchu minority). Surrounded by high and steep mountains, the township does not enjoy favourable endowments in arable land and the population pressure upon land is severe, with only a few $m и$ per capita.

Although it belongs to the rich municipality of Beijing, Labagoumen township is a rather poor area, as compared to both neighbouring townships and provinces ${ }^{6}$. The township is dominated by farm activities, the agricultural sector alone employing most of the active population.

The rural economy in this township has been traditionally relying on a subsistence agriculture. Although some villages turned to specialising in corn for seed, with a share of farmland area allocated to corn for seed as high as 83-88 per cent, this specialization structure remained quite far from the comparative advantage of the region. In recent years, a deeper economic restructuring has been fostered by the new context of rapid market development and 
tightening environmental restrictions and the township has started a process of moving away from food production and corn for seed to a wider range of activities, both within and out of the agricultural sector.

\section{1. On-farm diversification}

The market development that characterized China over the last decades has led to the commercialization of agricultural production, which is becoming more profit-oriented and increasingly guided by market conditions. Therefore, farmers in the township have started to convert some land from corn to higher value-added agricultural products, including American ginseng (Xiyangsen 西洋参) and medicinal plants. These productions are better related to the local comparative advantages in terms of climatic and topographic conditions and benefit from a direct access to the market through the regular inflow of tourists in the region. Moreover, farmers who turned to these new activities have benefited from various sets of preferential policies and subsidies ${ }^{7}$.

The most striking example of on-farm diversification changes concerns American ginseng. American ginseng culture started in the early 1980s in the whole county of Huairou and by 1990, the county was producing 10 tons of Ginseng per year, which represents one-fifth of the national production ${ }^{8}$. Within Labagoumen township, American ginseng is massively cultivated in Sidaoxue (四道穴) and in a lesser extent in Labagoumen village, Xiahebei (下 河北) and Zhongyudian (中榆店). In Sidaoxue, the cultivated area for American ginseng represents half of the total arable land. A specific feature of this evolution is that most of the production is made by non-villagers (from Tangkou 唐口, a neighbouring county of Hebei province) who rent the land from the village at a price of 400 yuan per $m u$ per year and enjoy a 5 year-tax delay from the village. This entails that most of the gains are made at the village level through land rental rather than by the villagers themselves ${ }^{9}$. 
Besides on-farm activities, both forestry and animal husbandry have also experienced deep changes over the last few years, mostly related to the implementation of recent forest policies. First, the logging ban imposed by the Natural Forest Protection Program since 1998 has severely hit the rural communities and villagers who were previously deriving important resources from wood production. All villages in the township depended heavily on forest resources, especially Maoshan (帽山) village, which major activity was timber production prior to the logging ban ${ }^{10}$. With the logging ban, all forest exploitation has been stopped and sawmills shut down. As a result, Maoshan village, which was one of the wealthiest in the area before the logging ban, suddenly became one of the poorest, most young laid-off workers moving out of the village after the closure of the sawmills.

Second, the implementation of the Sloping Land Conversion Program in the township since 2001, which provides subsidies for tree planting ${ }^{11}$, has encouraged households and villages to convert some of the agricultural land located on sloping land into forest land. Among the surveyed agricultural households, 30 per cent were involved in this programme, although participation rates differ substantially across villages. On average, 26 per cent of agricultural land had been converted by the end of 2003. Most of the land conversion (68 per cent of converted land) concerns economic trees (mainly chestnut trees, and marginally apricot trees and "Red fruit" 红果 trees), although some plots have been planted with poplar trees or fir trees. Although the main reason for land conversion is the implementation of the national policy, climatic and topographic conditions seem to provide the area with some comparative advantage in the activity. Moreover, while the program has further exacerbated tensions over scarce arable land in the area, related subsidies may be expected not only to compensate the induced income loss, but also to facilitate labour transfer to other activities through better food security and the release of liquidity constraints. 
Third, the establishment of a nature reserve in the township in December 1999 has further reinforced the restrictions on forest resources. To protect the region's forests and biodiversity, strict restrictions have been imposed on the collection of non-timber forest products as well as on animal husbandry. Protection measures thus require a deep restructuring of husbandry practice and radical changes from open-air grazing to rearing in enclosure. Thus, the goat herd has been gradually reduced in favour of new types of husbandry such as cows husbandry in one village (Zhongyudian) and battery chickens and ducks in other villages (Dongcha 东岔, Sidaoxue). These activities are mostly run by private households or household groups although in some cases, forms of collective husbandry can also be found. Here again, local governments (and in some instances villages) play an important role in diversification processes, by providing subsidies and/or preferential conditions that can appear as key factors in households' choices ${ }^{12}$. For instance, in Dongcha and Miaoying (苗营), subsidies and loans at a preferential rate have been provided by the local government for the construction of fences. In Dongcha, a private enterprise breeding battery-chicken, which is owned by a group of 25 households, has received financial support from the local government through zero per cent loans and subsidies.

In sum, both institutional reforms and environmental constraints induced by recent forestry policies have led to important restructuring in the agricultural sector in Labagoumen township. During these structural adjustments, local authorities have played a critical role in overcoming economic and environmental constraints, by providing innovative households with financial aid and policy support.

\section{2. Non-farm activities}

China's reform process has been accompanied by a massive migration phenomenon, of more than 100 million workers ${ }^{13}$. By providing additional income sources independent of the 
agricultural cycle, migration can increase both the level and the stability of household income $^{14}$. Owing to proximity to cities such as Huairou and Beijing and to a relatively welldeveloped infrastructure network in the region (most villages are served by a well-maintained national road), villagers, mostly young people, are engaged in migration, migrants accounting for almost 14 per cent of total active population. One quarter of rural households have at least one migration experience per year, mostly within Beijing municipality and households have on average 0.3 migrant. The share of migrants in labour force is higher in villages with fewer job opportunities, such as Zhongyudian (18 per cent), Sidaoxue ${ }^{15}$ (17 per cent) Miaoying ${ }^{16}$ (16 per cent) and Xiahebei (15 per cent) (Table 2). This finding is consistent with the existing literature, which usually finds that rates of out-migration are the highest in regions where local opportunities for diversifying activities are limited ${ }^{17}$. Indeed, migration is often a response to the narrow range of off-farm earnings opportunities in backward agricultural regions ${ }^{18}$. As shown in Table 2 , the scarcity of job opportunities has pushed younger and more educated workers to seek jobs outside the villages. The average number of years of schooling for migrants (7.1 years) is much higher than that of total active population (4.7 years), and the average age of migrants (32.8 years) is substantially lower than that of total active population (49.5 years). In 2003, migrants had been working on average 6 months outside their village and earned 10,143 yuan a year, almost twice the local average annual household cash income (5,400 yuan).

Tourism can also be seen as a worthwhile alternative to reconcile economic development imperatives and forest resource protection. In Labagoumen, the implementation of the Nature Reserve has led to the opening of family hotels, restaurants and the development of other tourism related activities. However, these activities are concentrated in one village only (Sunzhazi 孙栅子) where the reserve's entrance is located. While neighbouring villages benefit from marginal spillover effects ${ }^{19}$, most remote villages do not benefit at all from 
tourism development. In 2003, Sunzhazi, hosted a total of 29 family hotels and 4 restaurants involving 120 persons. Moreover, among the 50 households surveyed in Sunzhazi, 17 reported income from tourism related activities, with an average 8,000 yuan a year.

\section{The determinants of households' diversification behaviours}

As illustrated above, field observation reveals substantial disparities in activity restructuring and diversification between both households and villages in Labagoumen township. Although some households and villages are dynamic, the majority is characterised by a strong inertia. Except easily-accessible migration and arable land conversion into forests, which involve a large portion of households (respectively 23 per cent and 30 per cent), few villages and households had engaged in new activities in 2003. Most households were still heavily relying on corn production and many were not engaged in any alternative, more lucrative activity. As for on-farm restructuring, only a few households had converted their land from food production to American ginseng or other medicinal plants ${ }^{20}$. Similarly, few households had started husbandry businesses at a significant scale and tourism was mostly limited to one village.

Various explanations for diversification behaviours can be found to explain both incentives and disincentives for rural households to diversify. On the one hand, in a changing economic and institutional environment, rural households have incentives to find alternative income sources to secure their livelihood. But, on the other hand, several factors such as risk aversion, barriers to entry and historical impediments, can also hold them back from changing. 


\section{1. Incentives to diversification: pull and push factors}

A rich literature on income diversification in rural areas has identified a wide range of explanatory factors for activity restructuring out of subsistence farming at the household $\operatorname{level}^{21}$. These factors can be divided into two categories: "pull factors" and "push factors" 22 . Pull factors include benefits from complementarities between activities ${ }^{23}$, new income opportunities created by market development ${ }^{24}$, improvement of infrastructure ${ }^{25}$, and diversification for asset accumulation ${ }^{26}$. Push factors include $e x$ ante risk management ${ }^{27}$, ex post risk coping ${ }^{28}$, high transaction $\operatorname{costs}^{29}$, liquidity constraint and credit market failure ${ }^{30}$, and the seasonality of agricultural activity ${ }^{31}$.

Household livelihood strategies are jointly determined by these two sets of factors. On the one hand, market development encourages households to reallocate their productive resources to higher-return activities ${ }^{32}$. On the other hand, poor resource endowments, agricultural seasonality, frequent climatic hazards, and poor access to credit may all push rural households to undertake a wider range of activities in order to secure their livelihood.

Risks play a key role in the activity diversification process because they strongly influence rural production, income and welfare, and as such, are major "push" factors that encourage households to turn to a more diversified portfolio of activities ${ }^{33}$. As shown in many studies, households have incentives to combine traditional crops with new crops ${ }^{34}$, agricultural crops with animal husbandry or forestry activities ${ }^{35}$, and/or agricultural activities with off-farm activities such as migration and tourism ${ }^{36}$.

In China, risks are abundant in rural areas and risk incidence is heavy for rural households given the lack of credit and insurance markets. In particular, climatic risks are an important determinant of Chinese agricultural yield, with on average 30 per cent of Chinese sown area being affected by natural disasters every year during the period $1978-2003^{37}$. In the heart of a semi-dry area of northern China, Labagoumen township is substantially exposed to climatic 
risks, especially droughts. According to the Annals of Huairou county ${ }^{38}$ (怀柔县志), in the whole county, floods, droughts, hails and insect attacks occur on a regular basis.

Institutional reforms have brought additional sources of risk in the region, price risk being the most prominent for rural households, who were used to face only State procurement prices. Price risk is related to numerous imperfections in the market system that come from the uneven development process and the incompleteness of the reforms. Moreover, during any transition period, market prices of agricultural products are usually quite volatile and unpredictable, especially for new products whose market is often very thin and highly fragmented.

While rural households have no access to formal insurance mechanisms to cope with climatic and price risks, environmental protection measures implemented in Labagoumen township, have further weakened the few available informal insurance instruments. Indeed, the 1998 logging ban and restrictions imposed on husbandry have weakened two main insurance channels available to local populations: insurance provided by forest resources stock, and insurance provided by livestock. In this context, both on-farm and off-farm diversification can be seen as efficient mechanisms for households to reduce income risks ${ }^{39}$.

\subsection{Economic disincentives to diversification: risk aversion and barriers to entry}

Despite strong incentives to diversify activities, most households in the township have not engaged in any form of diversification. A set of factors can be identified to explain the low participation rate in new activities. First, on-farm diversification may be constrained by both the scarcity of land and land fragmentation in the township. Indeed, at the township level, arable land only accounts for three per cent of total land, while forest land represents 83 per cent. At the household level, the average farm size is less than half an hectare, which is too small to allow for effective diversification within agriculture. Moreover, since corn is the 
main crop, it may be less rational to diversify the production structure on such small plots rather than to keep the current production process on a network of plots belonging to different households.

Besides land constraint, households' reluctance to diversify can also be explained by risk aversion. Indeed, although rural households may have strong incentives to diversify their activity portfolio in order to reduce total income risks, not all of them can or want to do so. It is particularly true for the poorest households with high risk aversion, who can neither accept any new risk nor overcome barriers to entry in new activities.

New activities are often associated with new risks because of the lack of reliable information about the activity's return. There are usually little previous similar experiences in the neighbourhood and, for long term activities such as American ginseng culture, even though some households have engaged in the activity, the actual returns are still uncertain. Moreover, a rapidly changing and volatile environment, especially about prices, makes the evaluation of expected returns quite difficult. Uncertainty about project evaluation can make poor households reluctant to engage in new activities since the poorer the households, the higher their absolute risk aversion ${ }^{40}$. In Labagoumen township, many households are very close to poverty and fear that any activity failure may push them into poverty traps. Even though expected returns associated with alternative activities are higher and a more diversified portfolio of activities would certainly reduce the expected hazard of total income, most households prefer to stick to traditional crops for which risks are known. Therefore, risk aversion combined with poverty traps can help to explain why many households still allocate a high portion of land to food crops, which are crucial for their food security ${ }^{41}$. In our survey, agricultural households allocate on average 51 per cent of their arable land to food crops ${ }^{42}$, the proportion rising to 82 per cent when corn for seed is included. 
Many studies have shown that the rural poor have less access to lucrative alternative activities than their better-off counterparts because of high barriers to entry associated with these activities $^{43}$. One of the most important barriers is credit constraint. Indeed, a restricted access to credit and financial savings, where access is an increasing function of initial wealth, can impede both the purchase of livestock necessary for activity diversification out of crop agriculture $^{44}$ and the acquisition of lumpy assets (e.g. machinery, trucks, hotel or restaurant construction) essential to most non-farm activities ${ }^{45}$. Moreover, in Labagoumen township, most of the higher profit agricultural alternatives such as American ginseng, liquorice and tree planting require high initial investments and long delays ${ }^{46}$. It implies that households must find the required initial amount plus the necessary income to live on before they can receive any return from their investment (a few years for ginseng, more for fruit trees, and decades for timber plantation). However, most of the time, household savings are insufficient and external financing is scarce, except through government subsidies.

Regarding credit constraint, 44 per cent of surveyed households declared having faced a credit constraint over the last 5 years, with some important differences across villages (Table 3). 58 per cent of households reported borrowing over the last five years, mostly from parents (85 per cent), friends (53 per cent) and other persons (11 per cent), but rarely from institutional lenders such as credit cooperatives (four per cent), banks (five per cent) and local communities (three per cent) (Table 3). Among the 164 households who reported the reasons why they did not borrow from financial institutions, 62 per cent reported excessive required loan guarantees as well as restrictive and inflexible lending conditions as the main reason, followed by refusals from financial institutions ( 24 per cent), excessive interest rates (13 per cent) and the lack of financial institutions (one per cent). This tight credit constraint has definitely contributed to limiting the ability of households to undertake new activities that often require high initial investment. 
Besides financial constraints, another important barrier to entry to better remunerated activities lies in skills and education constraints ${ }^{47}$. In Labagoumen township as in many places in rural China, the education attainment of farmers is low, with only 4.7 years of schooling for an average worker. Unskilled poor have no choice but to stick to activities with low education requirements such as traditional crop cultivation. Even migration, although traditionally considered as an activity with relatively low barriers to entry, requires a higher educational attainment as shown above (Table 2). The low education level of households thus further reinforces inertia in terms of diversification behaviours. The recent reforms in China's education system characterized by the "marketization" of the educational sector and the sharp increase in educational costs for households may even worsen the situation in the future. Data from our survey show that a household with one child at school spends on average 4,350 yuan a year on educational expenditures, the figure rising to 7,592 yuan in the case of two children at school. Most households cannot afford such high educational costs, which leads to early dropping out of school just after, or even before the nine years of compulsory education. In the long run, the high cost of education may strongly limit the rural population's ability to enter into more skilled-labour intensive and more lucrative activities.

\subsection{Historical impediments}

An additional source of inertia in diversification behaviours comes from the reluctance of households to engage in activities that have already proven not to be lucrative or stable in the past. The recent local history shows several former bad experiences that tend to have a strong deterring effect on households involvement in new projects.

One illustrative case concerns husbandry practices. Some villages had introduced several years ago a special species of sheep from Shandong province to replace goats. The new sheep were kept in enclosures and were supposed to be sold at higher prices. However, these sheep 
could not adapt to the cold climate of the township and died at a very high rate. Other bad experiences concern unexpected price changes that have dramatically affected the expected returns for some activities. Hence, price volatility has been a major reason for the failure to develop liquorice culture, as some households in Huying (胡营) village, who entered liquorice cultivation several years ago, incurred substantial losses due to both significant price falls and high extraction costs at the harvest time.

Finally, a major factor relates to policy instability and forestry property rights insecurity. Indeed, during the implementation of recent environmental protection programs, some villages have radically changed their forest land-use policies, either by taking back distributed forest land from households or by forbidding timber harvest on contracted forest land. Bad experiences in this line include Xiahebei and Zhongyudian, where village committees took back some land previously distributed to peasants in order to take advantage of conversion policy subsidies. Similarly, in Maoshan, one household who had rented in from the village 17,000 $\mathrm{mu}$ of hill land for reforestation has been deprived of his right over this mountain land after the implementation of the logging ban in 1998, and fell into severe financial situation. Given the high occurrence of such cases over the last decades, households are quite reluctant to engage in long term activities like tree planting, which requires at least 30 years of stable land use right, or even American ginseng, which also requires a minimum of 3 to 5 years before harvest.

\section{Determinants of diversification: village strategies}

Even though farmers have been free to choose the crops they grow since the early 1980s, when the Household Responsibility System was introduced, their choice in terms of diversification still largely depends on villages strategies. Our field work suggests that large differences exist across villages in the speed of the activity restructuring process, which can 
be explained not only by differences in natural endowments, but also by differences in the village dynamism.

It clearly appears that important disparities across villages in resource endowments condition the village ability to create or seek income opportunities out of traditional cropping. Some fortunate villages are endowed with specific tourist sights or specific land characteristics, which attract outside investors and provide them with favourable initial conditions. For instance, in Sidaoxue, a large area of high-quality and flat land was conducive to American ginseng cultivation. Similarly, Sunzhazi is endowed with specific scenery that has ensured a natural development of tourism. These two "fortunate" villages are experiencing a natural diversification process, which does not require any specific intervention either from the village committee or from households.

Symmetrically, recent national forest protection measures have also had differentiated impacts on the different villages of the township. The logging ban and the establishment of the nature reserve have more deeply affected villages located inside the reserve and villages that were heavily dependent upon timber harvest before 1998. On the contrary, one village only (Sunzhazi) has benefited from the rapid development of tourism activities induced by the nature reserve establishment.

Besides natural differences in resource endowments, activity diversification also strongly depends on policies implemented at the local level to promote economic restructuring. Some dynamic villages did actively promote alternative activities through providing information as well as incentives, while some conservative villages did not promote any activity restructuring and even forbade this process by imposing grain production (mostly corn) to all households as can be observed in Dadianzi (大甸子), Labagoumen, and Zhongyudian. In dynamic villages, the range of measures that has been adopted to encourage activity restructuring includes cash subsidies, longer land-use right, and favourable terms (e.g. 
ginseng plantations in Sidaoxue), cash subsidies and training (e.g. collective plantation of medicinal plants in Huying) ${ }^{48}$, the personal involvement of the village head in reforestation (Miaoying), as well as numerous advantageous contracts for forest lands renting (Miaoying, Huying, and Sidaoxue). Private activities have also been strongly subsidized in some villages such as chicken battery in Dongcha and ducks for eggs in Sidaoxue.

A key determinant of the dynamism of villages in the diversification process is to be related with the characteristics of the village head and/or that of the party secretary. Indeed, village heads who have been party members and members of the village committee for years tend to be more conservative and less favourable to new activities than younger and better educated village heads. In the surveyed area, younger village heads also tend to be less risk averse and were usually personally involved in the new activities promoted by the village. In this respect, the case of Miaoying village head provides a good illustration. The village head has contracted a large area of forest land $(350 \mathrm{mu})$ in 1998 for poplar plantation, and several years later, he has set up a small civil engineering company to exploit the opportunities created by the government's large scale road improvement programme in rural areas. The involvement of local cadres in economic activity is a widespread phenomenon in rural China and has been widely discussed in the literature ${ }^{49}$. Indeed, since the beginning of the reforms, local governments and officials have been acting as both political regulators and economic agents seeking political merits and economic profits. This dual identity provides local cadres with strong incentives to promote the economic development of their jurisdiction, especially for the non-agricultural sector by using their political and economic power ${ }^{50}$.

The personal involvement of the village head can be expected to have two major positive effects: first, village heads set an example to other households and second, their personal involvement insures villagers against drastic changes in villages rules (especially concerning land use rights), at least in the medium term ${ }^{51}$. However, the involvement of village heads 
also holds potential drawbacks. Indeed, political and economic powers are closely linked and preferential conditions offered by the village to households involved in new activities may be a little too preferential. Since resources are usually limited, late comers may not have the opportunity to benefit from these advantages whereas village heads may well take the largest share. Again, the case of Miaoying village head is instructive. His renting in of forest land for tree planting has been made under very attractive terms $(26,000$ yuan to be paid within three years for $350 \mathrm{mu}$ of land over a lease period of 30 years). In the following years, other households realized the attractiveness of poplar planting, and disputed the remaining forest land under less favourable terms (lower quality of land and higher rent). Late comers found out that there was no more land to rent.

\section{Perspectives and policy implications}

Most recent studies on rural economy in developing countries have shown that activity adjustments are associated with higher and more stable income for both the richer and the poor $^{52}$. Using macroeconomic data from Chinese provinces between 1985 and 2001, Yang has shown that production restructuring from grain crops to cash crops and labour shift from cropping to non-agricultural activities have significantly contributed to rural income increase and income stability ${ }^{53}$. Similarly, we can expect that in Labagoumen township, households who participate in the activity diversification process will be better off.

However, the observed disparities between villages and households in terms of activity diversification can be expected to lead to an uneven distribution of economic wealth. First, differences in natural endowments have a direct impact on the relative position of neighbouring villages. Over the last ten years, the inequality structure has been entirely reshaped since the richest villages before 1998 were those endowed with large forest resources. These villages have suffered the most from the logging ban since they were 
usually endowed with the smallest arable land resources. Second, differences in village policies lead to different development patterns, which may entail important differences in income in the medium term. The same also applies to the distribution of income within villages since some households are engaging in new activities while others are not. At the time of the survey, the process was only at its very beginning but in the coming years, inequality within rural households can be reasonably expected to increase quite strongly.

In the absence of strong redistribution mechanisms, rising inequality is a source of social tensions and instability. In order to limit the rising rural discontent, it may thus be of special importance to help rural households, especially the poor, to start new activities by taking appropriate measures. Field interviews reveal that some preferential measures and subsidies have only benefited a minority of better-off households engaged in private lucrative businesses (ginseng cultivation, chicken and duck husbandry). Local cadres have a pivotal role to play here by targeting the poorest households in their subsidies or preferential loans and by reducing barriers to entry into new activities. They however usually have opposite incentives concerning their private interests.

In the studied area as well as in many parts of western China, villages are characterized by land scarcity and the absence of strong comparative advantages in agriculture activities. Increasing rural income mostly comes (and will have to come) from the development of offfarm activities, including the development of a local rural industry, tourism and migration. Conditions for success are based on the ability to reduce barriers to entry and to encourage the development of rural infrastructure and financial markets, the integration of the labour market as well as the improvement of education. On all these issues, State intervention through the lowering of education costs and the development of local credit institutions directed towards small-scale rural investments is still very much needed. 
Table 1 - Basic statistics for villages in Labagoumen township, 2003

\begin{tabular}{|l|c|c|c|c|c|c|c|}
\hline Villages & $\begin{array}{l}\text { Number of } \\
\text { households }\end{array}$ & Population & $\begin{array}{c}\text { Active } \\
\text { Population }\end{array}$ & $\begin{array}{c}\text { Agricultural } \\
\text { households }\end{array}$ & $\begin{array}{c}\text { Arable } \\
\text { land } \\
\text { (mu) }\end{array}$ & $\begin{array}{c}\text { Forest } \\
\text { land } \\
\text { (mu) }\end{array}$ & $\begin{array}{c}\text { Per capita } \\
\text { net income } \\
\text { in 1999 }\end{array}$ \\
\hline Maoshan & 333 & 837 & 450 & 333 & 1,200 & 72,000 & 2,691 \\
\hline Huying & 156 & 374 & 190 & 110 & 550 & 280,000 & 2,701 \\
\hline Sidaoxue & 175 & 430 & 235 & 175 & 599 & 18,000 & 3,904 \\
\hline Zhongyudian & 90 & 207 & 160 & 80 & 660 & 16,000 & 2,080 \\
\hline Xiahebei & 91 & 222 & 103 & 59 & 440 & 15,000 & 2,317 \\
\hline Sunzhazi & 237 & 641 & 300 & 237 & 1,213 & 53,000 & 3,718 \\
\hline Miaoying & 118 & 332 & 160 & 118 & 806 & 30,600 & 3,108 \\
\hline Labagoumen & 225 & 548 & 270 & 150 & 876 & 35,000 & 3,594 \\
\hline Dadianzi & 170 & 500 & 310 & 170 & 4,000 & 14,000 & 3,058 \\
\hline Dongcha & 183 & 539 & 270 & 130 & 1,000 & 79,000 & 2,023 \\
\hline Sourc:
\end{tabular}

Source: Household survey conducted in 2003. Data drawn from the village questionnaire. 
Table 2 - Migration in Labagoumen township between 1999 and 2003

\begin{tabular}{||c|cc|c|c|cc|cc||}
\hline \multirow{2}{*}{ Village } & Migrants per household & $\begin{array}{c}\text { Working time } \\
\text { in 2003 }\end{array}$ & Income in 2003 & \multicolumn{2}{|c|}{ Years of schooling } & Average age \\
\cline { 2 - 9 } & \# persons & $\begin{array}{c}\text { Share in active } \\
\text { population }\end{array}$ & Months & Yuan & Migrants & $\begin{array}{c}\text { Active } \\
\text { population }\end{array}$ & Migrants & $\begin{array}{c}\text { Active } \\
\text { population }\end{array}$ \\
\hline Dadianzi & 0.32 & $15.3 \%$ & 6.0 & 15,812 & 7.8 & 5.3 & 28.7 & 51.0 \\
Dongcha & 0.23 & $9.5 \%$ & 5.6 & 4,750 & 8.3 & 4.6 & 27.0 & 52.2 \\
Huying & 0.30 & $11.9 \%$ & 2.0 & 2,775 & 5.6 & 4.2 & 42.7 & 52.0 \\
Labagoumen & 0.23 & $9.3 \%$ & 7.5 & 25,525 & 9.5 & 5.6 & 34.5 & 49.7 \\
Maoshan & 0.19 & $10.0 \%$ & 5.0 & 4,967 & 5.4 & 4.0 & 28.8 & 48.5 \\
Miaoying & 0.40 & $16.0 \%$ & 3.0 & 9,333 & 8.2 & 4.4 & 36.8 & 49.2 \\
Sidaoxue & 0.28 & $16.7 \%$ & 9.7 & 6,000 & 6.3 & 4.3 & 32.6 & 49.9 \\
Sunzhazi & 0.38 & $14.4 \%$ & 5.6 & 3,450 & 7.4 & 5.2 & 30.4 & 45.9 \\
Xiahebei & 0.27 & $15.4 \%$ & 6.3 & 5,500 & 8.9 & 4.3 & 30.6 & 51.7 \\
Zhongyudian & 0.40 & $17.5 \%$ & 10.5 & 25,250 & 4.4 & 4.7 & 35.1 \\
\hline Total sample & $\mathbf{0 . 3 0}$ & $\mathbf{1 3 . 7 \%}$ & $\mathbf{6 . 1}$ & $\mathbf{1 0 , 1 4 3}$ & $\mathbf{7 . 1}$ & $\mathbf{4 . 7}$ & $\mathbf{3 2 . 8}$ & 45.9 \\
\hline
\end{tabular}

Notes: Numbers are household averages.

Source: Household survey conducted in 2003. 
Table 3 - Borrowing behaviours and access to credit, 1999-2003

\begin{tabular}{|c|c|c|c|c|c|c|c|c|c|}
\hline \multirow[b]{2}{*}{ Village } & \multicolumn{2}{|c|}{ Borrowing households } & \multicolumn{6}{|c|}{ Lenders (as a percentage of borrowing households) ${ }^{\text {b }}$} & \multirow{2}{*}{$\begin{array}{l}\text { Credit } \\
\text { constraint } \\
\text { ratio }^{c}\end{array}$} \\
\hline & Households & Share ${ }^{a}$ & Parents & Friends & $\begin{array}{c}\text { Other } \\
\text { persons }\end{array}$ & $\begin{array}{c}\text { Credit } \\
\text { cooperatives }\end{array}$ & Bank & Collectives & \\
\hline Dadianzi & 15 & $48 \%$ & $100 \%$ & $53 \%$ & $0 \%$ & $7 \%$ & $0 \%$ & $0 \%$ & $46 \%$ \\
\hline Dongcha & 22 & $71 \%$ & $91 \%$ & $36 \%$ & $5 \%$ & $9 \%$ & $9 \%$ & $14 \%$ & $39 \%$ \\
\hline Huying & 18 & $60 \%$ & $83 \%$ & $67 \%$ & $28 \%$ & $6 \%$ & $17 \%$ & $0 \%$ & $33 \%$ \\
\hline Labagoumen & 13 & $43 \%$ & $85 \%$ & $85 \%$ & $46 \%$ & $15 \%$ & $0 \%$ & $0 \%$ & $43 \%$ \\
\hline Maoshan & 15 & $50 \%$ & $93 \%$ & $60 \%$ & $7 \%$ & $7 \%$ & $7 \%$ & $0 \%$ & $42 \%$ \\
\hline Miaoying & 16 & $53 \%$ & $94 \%$ & $56 \%$ & $0 \%$ & $6 \%$ & $0 \%$ & $0 \%$ & $45 \%$ \\
\hline Sidaoxue & 13 & $46 \%$ & $85 \%$ & $31 \%$ & $0 \%$ & $8 \%$ & $8 \%$ & $0 \%$ & $29 \%$ \\
\hline Sunzhazi & 32 & $64 \%$ & $69 \%$ & $72 \%$ & $19 \%$ & $0 \%$ & $6 \%$ & $0 \%$ & $45 \%$ \\
\hline Xiahebei & 19 & $63 \%$ & $84 \%$ & $42 \%$ & $11 \%$ & $5 \%$ & $0 \%$ & $0 \%$ & $55 \%$ \\
\hline Zhongyudian & 21 & $70 \%$ & $81 \%$ & $52 \%$ & $19 \%$ & $0 \%$ & $5 \%$ & $5 \%$ & $59 \%$ \\
\hline Total sample & 184 & $58 \%$ & $85 \%$ & $53 \%$ & $11 \%$ & $4 \%$ & $5 \%$ & $3 \%$ & $44 \%$ \\
\hline
\end{tabular}

Notes: a. Share of households who have borrowed money during the last 5 years in the total number of surveyed households. b. The sum of all lenders may exceed $100 \%$, since households can borrow from more than one source. c. Share of households facing credit constraint in the total number of surveyed households.

Source: Household survey conducted in 2003. 
Table 4 - Village heads' characteristics

\begin{tabular}{|c|c|c|c|c|c|c|c|}
\hline Village & $\overline{\text { Age }}$ & Education & $\begin{array}{c}\text { Start } \\
\text { function }\end{array}$ & $\begin{array}{l}\text { Former } \\
\text { activity }\end{array}$ & $\begin{array}{c}\text { Number of } \\
\text { years in } \\
\text { this post }\end{array}$ & $\begin{array}{c}\text { Party } \\
\text { member }\end{array}$ & $\begin{array}{c}\text { Last time } \\
\text { elected }\end{array}$ \\
\hline Dadianzi & 35 & $\begin{array}{c}\text { Technical } \\
\text { high school }\end{array}$ & 1995 & Peasant & 8 & Yes & 2001 \\
\hline Dongcha & 42 & $\begin{array}{c}\text { Technical } \\
\text { high school }\end{array}$ & 1995 & Peasant & 8 & Yes & 2001 \\
\hline Huying & 44 & $\begin{array}{c}\text { Technical } \\
\text { high school }\end{array}$ & 1994 & Peasant & 9 & Yes & 2001 \\
\hline Labagoumen & 43 & High school & 1996 & Entrepreneur $^{1}$ & 7 & Yes & 2001 \\
\hline Maoshan & 45 & Primary & 2002 & Cadre & 8 & Yes & 2002 \\
\hline Miaoying & 39 & $\begin{array}{c}\text { Technical } \\
\text { high school }\end{array}$ & 1998 & $\begin{array}{l}\text { Entrepreneur } \\
\text { (transport) }\end{array}$ & 6 & Yes & 2001 \\
\hline Sidaoxue & 60 & $\begin{array}{l}\text { Junior high } \\
\text { school }\end{array}$ & 1992 & Cadre & 30 & Yes & 2001 \\
\hline Sunzhazi & 45 & $\begin{array}{c}\text { Technical } \\
\text { high school }\end{array}$ & 2001 & Accountant & 20 & Yes & 2001 \\
\hline Xiahebei & 35 & High school & 2001 & $\begin{array}{l}\text { Worker in } \\
\text { Huairou }\end{array}$ & $2^{2}$ & No & 2001 \\
\hline Zhongyushu & 42 & $\begin{array}{c}\text { Technical } \\
\text { high school }\end{array}$ & 1995 & Cadre & 18 & Yes & 2001 \\
\hline
\end{tabular}

Notes:

1. Former manager of a firm specialized in farm equipment repairing which no longer exists.

2. The former village head resigned in July 2003 to devote all his time to his own transport business. Since then, the Party Secretary (44 years old, graduate of technical high school and local cadre since 1978) holds concurrently both functions of village head and party secretary.

Source: Household and village survey conducted in 2003. 


\section{Map 1 - Labagoumen township and surveyed villages}

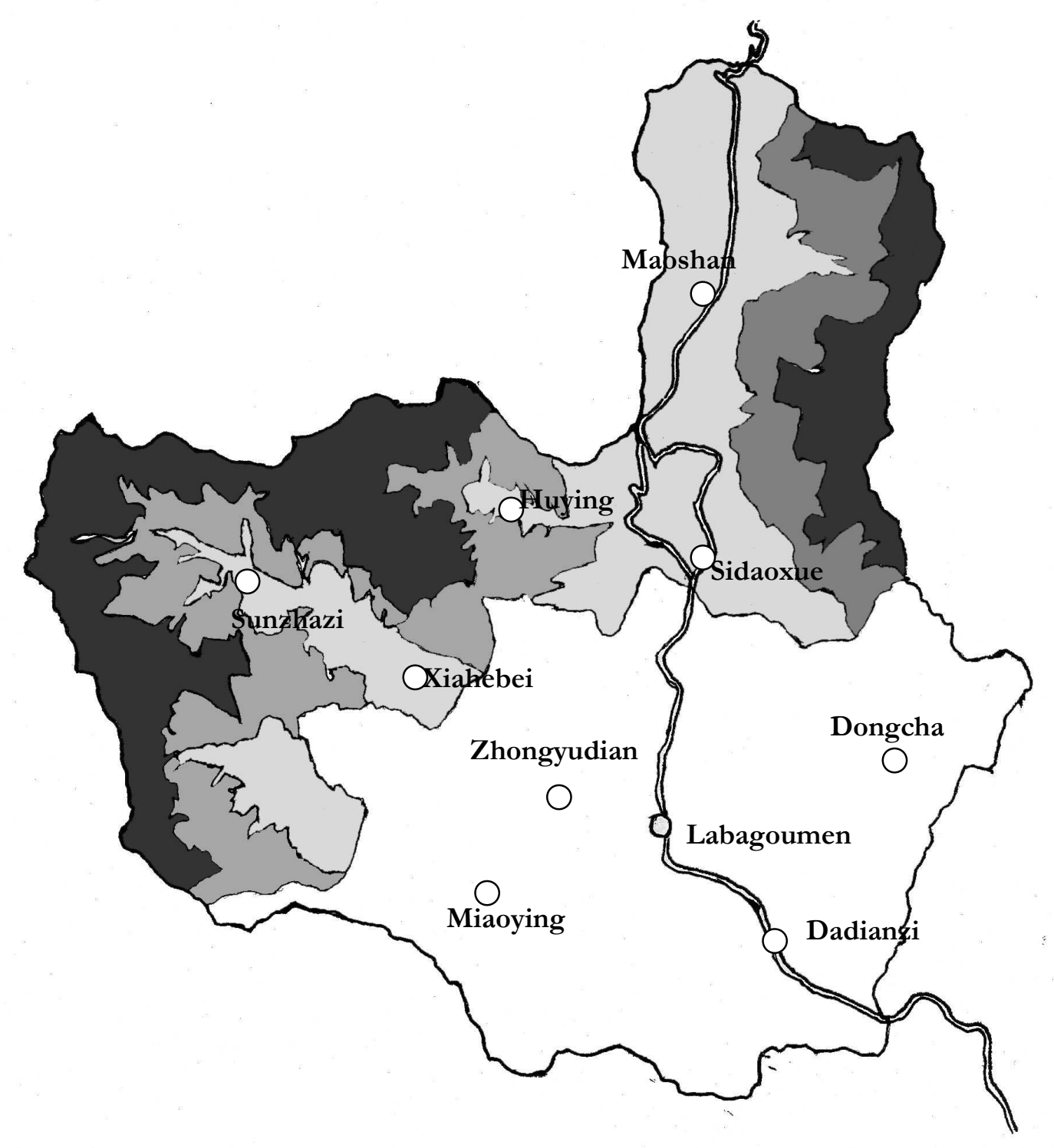

Source: Cui et al., "The establishment and the functional area's division of Lagaboumen reserve in Beijing", Journal of Beijing Forestry University, Vol. 22, No. 4 (2000), pp. 40-45.

Notes: Villages are located approximately by the authors. Different colours represent the three different zones (core zone / buffer zone / experimental zone) in the Nature Reserve. 
${ }^{1}$ Christopher L. Delgado and Ammar Siamwalla, "Rural Economy and Farm Income Diversification in Developing Countries”, MSSD Discussion Paper No. 20, October 1997.

${ }^{2}$ C. Barrett, M. Bezuneh, and A. Abdillahi, "Income diversification, poverty traps and policy shocks in Cote d'Ivoire and Kenya", Food Policy, Vol. 26, No. 4 (2001), pp. 367-384; M.R. Carter, "Environment, Technology, and the Social Articulation of Risk in West African Agriculture", Economic Development and Cultural Change, Vol.45, No. 3 (1997), pp. 557-591.

${ }^{3}$ F. Ellis, "Household strategies and rural livelihood diversification in developing countries", Journal of Agricultural Economics, Vol. 51, No. 2 (1998), pp. 289-301; F. Ellis, Rural Livelihoods and Diversity in Developing Countries (Oxford: Oxford University Press, 2000); T. Reardon, J. Taylor, K. Stamoulis, P. Lanjouw and A. Balisacan, "Effects of non-farm employment on rural income inequality in developing countries: An investment perspective", Journal of Agricultural Economics, Vol. 51, No.2 (2000), pp. 266-288; S. Canagarajah, C. Newman, and R. Bhattamishra, "Non-farm income, gender, and inequality: Evidence from rural Ghana and Uganda", Food Policy, Vol. 26, No. 4 (2001), pp. 405-420; S. Block and P. Webb, "The dynamics of livelihood diversification in post-famine Ethiopia”, Food Policy, Vol. 26, No. 4 (2001), pp. 333350.

${ }^{4}$ Sylvie Démurger, Martin Fournier and Guozhen Shen, "Forest Protection Policies: National Guidelines and Their Local Implication in Northern Sichuan”, China Perspectives, No. 59, May-June 2005, pp. 1-12.

${ }^{5}$ Sylvie Démurger and Martin Fournier, "Rural poverty and fuelwood consumption: Evidence from Labagoumen Township (China)", GATE Working paper, 2006.

${ }^{6}$ In terms of per capita GDP, Labagoumen township is the second poorest township in Huairou county, with 5,668 Yuan (approx. 2,715 PPP\$) per capita in 1999.

${ }^{7}$ Instruments of preferential policies and subsidies vary across villages. In Xiahebei, government subsidies of 500 yuan, plus $50 \mathrm{~kg}$ of cereal per $m u$ have been given to households who started American ginseng culture. In Zhongyudian, besides a subsidy of 400-500 yuan per $m u$, loans at zero per cent were also offered to households starting American ginseng culture.

${ }^{8}$ Huairou xianzhi (Annals of Huairou county), (Beijing: Beijing Publishing House, 2000).

${ }^{9}$ Eleven households from the village cultivate $50 \mathrm{mu}$ of American ginseng and 30 additional households are employed by non-villagers to work on their ginseng plots.

${ }^{10}$ Two sawmills employing about 30 persons have been shut down, with a total revenue loss estimated by the village head as high as 250,000 Yuan a year.

${ }^{11}$ Land conversion subsidies were $70 \mathrm{~kg}$ fine cereal (flour or husked rice) plus 20 yuan for each converted $m u$ at the time of the survey.

${ }^{12}$ However, unlike land conversion, it is not clear whether there is a strong comparative advantage for such activities or not. In particular, winter is quite cold in the area and poultry batteries have to be heated.

${ }^{13}$ Scott Rozelle, Jikun Huang and Linxiu Zhang, "Emerging Markets, Evolving Institutions, and the New Opportunities for Growth in China's Rural Economy”, China Economic Review, Vol. 13, 2002, pp. 345-353.

${ }^{14}$ Ellis, Rural Livelihoods and Diversity in Developing Countries; J.G.M. Hoogeveen, "Income Risk,

Consumption Security and the Poor", Oxford Development Studies, Vol. 30, No. 1 (2001), pp.105-121; H.

Alderman and C.H. Paxson, "Do the Poor Insure? A Synthesis of the Literature on Risk and Consumption in Developing Countries”, Discussion Paper No. 164 (Princeton: Princeton University, Woodrow Wilson School, 1992).

${ }^{15}$ In Sidaoxue, out-migration can be explained by good transport infrastructure since the village is located along the national road, and by the fact that many villagers have rented out their land to outsiders for ginseng cultivation.

${ }^{16}$ In Miaoying, the massive implementation of the Sloping Land Conversion Program can partly explain outmigration, workers released from agriculture seeking jobs outside the village.

${ }^{17}$ Chan Kam Wing and Yang Yunyan, "Internal Migration in Post-Mao China: A Dualistic Approach", in China Population Association (ed.), Symposium on Demography of China (Beijing: China Population Association, 1997), pp. 179-197.

${ }^{18}$ Rachel Murphy, "Return Migrant Entrepreneurs and Economic Diversification in Two Countries in South Jiangxi, China", Journal of International Development, Vol. 11, 1999, pp. 661-672; Rachel Murphy, How Migrant Labor is Changing Rural China, Cambridge: Cambridge University Press, 2002).

${ }^{19}$ Spillover effect on neighbouring villages were to be seen in Miaoying (15 family hotels ready to receive tourists in 2003) and Maoshan (12 family hotels). Two other villages (Huying and Sidaoxue) also had a tourism development project for the coming years after 2003.

${ }^{20}$ In a total sample of 282 agricultural households, only 8 households (merely $3 \%$ distributed in three villages) have engaged in ginseng cultivation. 
${ }^{21}$ Awudu Abdulai and Anna CroleRees, "Determinants of Income Diversification amongst Rural Households in Southern Mali”, Food Policy, Vol.26, 2001, pp.437-452; D. R. Smith, A. Gordon, K. Meadows and K. Zwick, "Livelihood diversification in Uganda: Patterns and determinants of change across two rural districts", Food Policy, Vol. 26, No. 4 (2001), pp. 421-435; Ellis "Household strategies and rural livelihood diversification", pp. 289-301.

${ }^{22}$ C. Barrett, T. Reardon and P. Webb, "Non-farm income diversification and household livelihood strategies in rural Africa: Concepts, issues, and policy implications", Food Policy, Vol. 26, No. 4 (2001), pp. 315-331.

${ }^{23}$ D.W. Norman, "Rationalising Mixed Cropping under Indigenous Conditions: The Example of Northern Nigeria”, The Journal of Development Studies, Vol.11, No.1 (1974), pp. 3-21.

${ }_{24}$ J. Davis, and D. Pearce, 2001, "The rural non-farm economy in Central and Eastern Europe", in Z. Lerman and C. Csaki (ed.), The Challenge of Rural Development in the EU Accession Process (Washington DC: World Bank, 2001).

${ }^{25}$ J. Jalan, and Martin Ravallion, “Geographic poverty traps?”, Discussion Paper No. 86 (Boston: Institute for Economic Development, Boston University, 1998).

${ }^{26}$ G. Hart, "The Dynamics of Diversification in an Asian Rice Region", in B. Koppel, John N. Hawkins, William E. James (ed.), Development or Deterioration?: Work in Rural Asia, (Boulder, CO: Lynne Reinner, 1994), pp. 47-71.

${ }^{27}$ Hoogeveen, "Income Risk, Consumption Security and the Poor", pp. 105-121; Alderman and C.H. Paxson,

"Do the Poor Insure?".

${ }^{28}$ Carter, "Environment, Technology, and the Social Articulation of Risk", pp. 557-591.

${ }^{29}$ Steven Omamo, "Transport Costs and Smallholder Cropping Choices: An Application to Siaya District, Kenya", American Journal of Agricultural Economics, Vol.80, No.1 (1998), pp. 116-123.

${ }^{30}$ T. Reardon, E. Crawford, and V. Kelly, "Links between non-farm income and farm investment in African households: Adding the capital market perspective", American Journal of Agricultural Economics, Vol. 76, No. 5 (1994), pp. 1172-1176.

${ }^{31}$ D. E. Sahn, Seasonal Variability in Third World Agriculture: The Consequences for Food Security (Baltimore, MD: John Hopkins Press, 1989).

${ }^{32}$ In the case of North-east China, see Qingjie Xia and Colin Simmons, "Diversify and Prosper: Peasant Households Participating in Emerging Markets in Northeast Rural China”, China Economic Review, Vol. 15, No. 4 (2004), pp. 375-397.

${ }^{33}$ Carter, "Environment, Technology, and the Social Articulation of Risk", pp. 557-591; T. Reardon, C. Delgado and P. Matlon, "Determinants and Effects of Income Diversification Amongst Farm Households in Burkina Faso", The Journal of Development Studies, Vol.28, No. 2 (1992), pp. 264-296.

${ }^{34}$ Norman, "Rationalising Mixed Cropping under Indigenous Conditions", pp. 3-21.

${ }^{35}$ Takashi Kurosaki, 1995, "Risk and Insurance in a Household Economy: Role of Livestock in Mixed Farming", The Developing Economies, Vol. XXXIII, No. 4 (1995), pp. 464-485; Takashi Kurosaki, "Production Risk and Advantages of Mixed Farming in the Pakistan Punjab", The Developing Economies, Vol. XXXV, No. 1 (1997), pp. 28-47.

${ }^{36}$ Barrett, Reardon and Webb, "Non-farm income diversification and household livelihood strategies in rural Africa”, pp. 315-331; Murphy, "Return Migrant Entrepreneurs and Economic Diversification”, pp. 661-672.

${ }^{37}$ National Bureau of Statistics, China Statistical Yearbook (Beijing: China Statistics Press, 1981-2004).

${ }^{38}$ Huairou xianzhi.

${ }^{39}$ Ellis "Household strategies and rural livelihood diversification", pp. 289-301; Ellis, Rural Livelihoods and Diversity in Developing Countries; Hoogeveen, "Income Risk, Consumption Security and the Poor", pp. 105121.

${ }^{40}$ M. Rosenzweig and H.P. Binswanger, "Wealth, Weather Risk and the Composition and Profitability of Agricultural Investments”, Economic Journal, Vol. 103, 1993, pp.56-78.

${ }^{41}$ The ageing of local population and the massive migration of young people may also increase risk aversion within rural households.

${ }^{42}$ Food crops include corn, soy bean, sorghum, sweet potato, rice, millet, peas and wheat.

${ }^{43}$ Barrett, Reardon and Webb, "Non-farm income diversification and household livelihood strategies in rural Africa", pp. 315-331, Barrett, Bezuneh and Abdillahi, "Income diversification, poverty traps and policy shocks in Cote d'Ivoire and Kenya", pp. 367-384; Abdulai and CroleRees, "Determinants of Income Diversification amongst Rural Households", pp.437-452; T. Woldenhanna and A. Oskam, "Income Diversification and Entry Barriers: Evidence from the Tigray Region of Northern Ethiopia", Food Policy, Vol.26, 2001, pp.351-365.

${ }^{44}$ Stephan Dercon, "Wealth Risk and Activity Choice: Cattle in Western Tanzania", Journal of Development Economics, Vol.55, 1998, pp. 1-42.

${ }^{45}$ C. B. Barrett, "Food Marketing Liberalization and Trader Entry: Evidence from Madagascar", World Development, Vol. 25, No. 5 (1997), pp. 763-777. 
${ }^{46}$ For example, the initial investment to plant American ginseng is 15,000 yuan per $m u$ over 5 years (and mostly during the first year). However, the expected net benefit from selling after 5 years is 45,000 yuan per $m u$.

${ }^{47}$ Smith, Gordon, Meadows and Zwick, "Livelihood diversification in Uganda", pp. 421-435.

${ }^{48}$ In order to encourage households to undertake this activity, the village government itself cultivated $10 \mathrm{mu}$ of medicinal plants to set an example.

${ }^{49}$ See in particular Oi's definition of "local state corporatism". Jean Oi, Rural China Takes Off: Institutional Foundations of Economic Reform (Berkeley: University of California Press, 1999).

${ }^{50}$ Susan Whiting, Power and Wealth in Rural China: The Political Economy of Institutional Change

(Cambridge: Cambridge University Press, 2001).

${ }^{51}$ It can also be argued that doing so, village heads also secure votes for the next elections.

${ }^{52}$ Block and Webb, "The dynamics of livelihood diversification in post-famine Ethiopia", pp. 333-350;

Hoogeveen, "Income Risk, Consumption Security and the Poor", pp. 105-121.

${ }^{53}$ Weiyong Yang, 2006, "Reforms, Structural Adjustments, and Rural Income in China", China Perspectives, No. 63, 2006, pp. 27-33. 